\title{
TRUST DIMENSIONS IN THE BUSINESS RELATIONSHIP
}

\author{
Eglè KAZLAUSKIENÉ \\ Mykolas Romeris University \\ Ateities str. 20, LT-08303 Vilnius, Lithuania \\ E-mail: egle.kazlauskiene@mruni.eu \\ Ilona BARTUŠEVIČIENĖ \\ Mykolas Romeris University \\ Ateities str. 20, LT-08303 Vilnius, Lithuania \\ E-mail: ilona.bartuseviciene@mruni.eu \\ doi:10.13165/IE-13-7-4-08
}

\begin{abstract}
In recent years, the aspect of trust in the context of inter-organizational relationship has deserved an increased attention from foreign scientists. The importance of investigation has been shown by a growing number of publications on the role of trust in international relations. The interest in this field of study, on the one hand, was determined by the changes in the business environment. The abundance of information, the appearance of network organizations, dynamics of environment conditions and the need for innovations lead the companies to a greater or smaller trust in business partners. Another reason lies in the positive effect of trust for successful interorganizational relationship. The trust in an organization also means trust in its people working in this organization. It affects the fact that the assesment of trust in business partners can be related to the highlighting of the aspects of psychology as well as behavior of the individuals. On the other hand, this evaluation may be related to the identification of the trust evaluation criteria (both in the level of individuals and organizations) and determination of the reasons of trust formation.
\end{abstract}

JEL classification: M21, D23, L14.

Keywords: trust, business relationship, trust levels and forms, reasons for trust formation, trust criteria.

Reikšminiai žodiai: pasitikejimas, verslo santykiai, pasitikejjimo lygmenys ir formos, pasitikẻjimo formavimosi priežastys, pasitikèjimo kriterijai.

\section{Introduction}

Recently, trust dimension within business relationship context has attracted an increased attention of foreign scholars. The interest in this research subject has been mainly impacted by the changes in the business environment. The abundance of information, 
dynamics in the environmental conditions and the need for innovation make companies more or less rely on business partners. According to Zanini and Musante (2013), trust relationships have become a highly desirable property not only as informal coordination mechanism, but also as a competitive advantage in the new business environment.

Another reason lies within the positive impact of the trust while creating and developing high performance, valuable inter-relationships among different businesses. The trust enhances the effectiveness of the business functioning and remains the main condition for any kind of relationship creation and development, including inter-relationships among business partners.

The assessment of business partner's trust is a complex objective. Trust in the organization equals trust in the staff, performing in the organization, which leads to the formulation of the scientific problem - what is the composition of the trust dimension within an individual as well as organizational level?

The objectives of this article are the following: 1) to reveal theoretical aspects of the trust formation in the business relationship, exploring the concepts of the trust, its forms and levels; 2) to identify the reasons for trust formation within business relationship; 3 ) to exclude the criteria/components for the trust assessment, presenting the empirical research results.

\section{Theoretical aspects of the trust formation in the business relationship}

The aspects of trust formation among business partners. Recently, scholars have been enhancing their focus on the trust concept, which is highly valued within business relationship creation and development. The importance of the trust can be explained as a key ingredient, contributing to interpersonal relations, internal company relationships and inter-organizational relationship building. Forming business relationship, each organization in the market is free to choose partners. In order to find external sources of supply and product marketing opportunities, an organization has to cooperate with other companies and start building the networks.

On the one hand, network based relationship establishment and development require a long period of time, effort and financial recourses, which, in case there is a need to change a business partner, is not easily and quickly accomplished, due to the transactional cost. On the other hand, business relationship is formed between partners in the ongoing process of resource exchange. Single exchanges are an integral part of the organization's relationship formation, when partners, in the adaptation process, start gradually building mutual trust.

It is important to stress the fact that incomplete or distorted information presentation can occur while being in the development of business relationship adaptation process. Such opportunistic behavior occurs when one organization finds the opportunity to maximize its own profits at the expense of mutual relations. This may lead to a lack of confidence and reciprocal behavior. Mutual trust in business is rarely formed spontaneously; rather, it arises from the experience gained over a long period of interaction with 
a business partner. Trust is dynamic, where the outcome and the reasons depend on the partner's mutual understanding of business relationships. This is one of the outcomes or the results of the business inter-relationship process formation.

\section{Trust concept, forms and levels}

Trust in business relationships can be examined from different perspectives and within dissimilar context, it includes non-violent action and the voluntary binding diversity; according to it, partners help each other, provide information and support in other ways of mutual cooperation. According to Lane (2000), trust is the belief or expectation that potential loss, which can occur due to the cooperation risk, will not become a benefit for another organization. Expectations can be directed to the value of standards. These expectations may be calculative, value or norm based, or based on common cognitions (Batt, 2003). According to Vollan (2011), trust consists of expectation having a positive influence on the social actor and is formulated under conditions of uncertainty. In other words, one can talk of trust in a situation, where an actor is not sure of what the other will do, but has good reasons to be confident that the latter will conform to his or her own expectations (Tejpal, Garg and Sachdeva, 2013). McKnight and Webster (2001) distinguished between these levels of trust: individual, interpersonal/intergroup and institutional/cultural (Martins, 2002). Payan (2006) focused also on interpersonal and interfirm trust.

According to Wehmeyer and Riemer (2007), trust is often seen as a psychological state; therefore, only individuals can share the trust. This argument is supported by Thuy and Quang (2005), they argue that trust between organizations is often understood as the existence of trust between individuals from different organizations. That is to say, cooperation between organizations often form close personal relationships among the representatives of these organizations, thus forming interpersonal trust level. Nevertheless, the trust formed at the interpersonal level does not reflect the trust that exists between the business partners. According to Ambrose and Fyne (2005), inter-organizational trust can be understood in two ways: as a trust, when a representative of the organization trusts another representative from a different organization, or a trust, where a representative of the organization has a trust in another organization as a whole.

There is no solid opinion regarding trust dimension levels, although it is important to emphasize that business trust relies on the trust of the individuals; therefore, human personal qualities, their ability to participate in the business relationship development process have a severe impact on the overall trust.

According to Tejpal, Garg and Sachdeva (2013), trust can be identified in different forms:

- Characteristic trust. Characteristic perspective of trust deals with factors, such as perceptions, reliability, dependability, credibility, commitment, honesty, benevolence, fairness, goodwill, emotions, etc.

- Rational trust deals with factors, such as economics of relationship, dynamic capabilities of partners and technology adoption.

- Institutional trust deals with factors, such as control mechanisms between members through legal frameworks, commercial law, contracts, agreements, bank guarantees and insurance (Child and Mollering, 2003). 
- Anticipatory trust is the kind of trust, in which someone trusts the other, since one expects him or her to act routinely. It is the normal pattern of behavior that forms the foundation for trust. The main element in the (implicit) decision to trust is the analogy between the present case and former cases, in which the other has acted in a trustworthy way.

- Responsive trust. The main vulnerability of responsive trust is that presupposed shared moral values do not necessarily lead to trust.

- Calculus-based trust and identification-based trust. Calculus-based trust (CBT) and identification-based trust (IBT) are different. In CBT, which is most often related to the workplace, people tend to operate on a reward punishment system (Lewicki and Wiethoff, 2000). The value in completing a task or a goal is not seen as personal satisfaction, but rather because of the consequences of doing so. In CBT, trust is built slowly. (Tejpal, Garg and Sachdeva, 2013).

Zucker (1986) describes trust between organizations in context of process-based trust, characteristic-based and institutional-based trust:

1. Process-based trust is derived from a social system of mutual obligations, where each partner has clear expectations of the other's behavior.

2. Characteristic-based trust is tied to specific individuals, where various demographic features serve as indicators of membership to a common cultural system with shared expectations.

3. Institutional-based trust rests both on the membership in subculture, within which clearly delineated expectations are held, and from various intermediary mechanisms that the trustee undertakes to protect the interest of both partners. (Batt, 2003).

Trust is described as interpersonal and impersonal. Interpersonal trust is something, which is essentially personal, relational and which exists between two parties, a trustor and a trustee (Husted, 1998). It can only be granted by, and gained from, individuals, whether singly or as part of a wider group. It involves emotions and values and it evolves from our experience of working with others. Trust requires not only the confidence that another shares, the commitment, but the belief that he or she will not take any actions which would be harmful to the interests and, further, that he or she will proactively seek to protect the position, thus reducing vulnerability (Skinner and Spira, 2003).

Sako (1992) finds it necessary to differentiate between contractual trust, competence trust and goodwill trust:

1. Contractual trust rests on the moral norm of honesty and keeping promises.

2. Competence trust is based on the expectation that the trading partner will perform its role competently.

3. Goodwill trust is described as willingness of the exchange partner to do more than expected (Batt, 2003).

This expectation of trust is confirmed when parties (1) demonstrate reliability by carrying out their promises, (2) act fairly when dealing with each other, and (3) exhibit goodwill when unforeseen contingencies arise. 
In analyzing trust, some authors emphasize its psychological aspect (Rousseau, Sitkin, Burt and Camerer, 1998), while others point to the behavioral one (McAllister, 1995). Sarkar, Cavusgil and Evirgen (1997) emphasize the importance of both of these aspects. The psychological state point of view defines trust in terms of interrelated cognitive processes and orientations towards beliefs or positive expectations in relation to others. Some definitions apply to contexts, where these others are identifiable, such as in Rousseau, Stikin, Burt and Carmerer, "trust is a psychological state comprising the intention to accept vulnerability based upon positive expectations of the intentions or behavior of another". In other definitions, trust is presented as a more general attitude or expectancy about other people or about the general social system. Common to these definitions is the reference to states of "vulnerability", "confidence", and "positive expectations" (Janowicz and Noorderhaven, 2002).

Trust as a choice of behavior can be seen as the willingness to take risks by acting on the basis of words, actions or decisions of others. In some definitions, trust is viewed as a more or less rational decision, motivated primarily by perception of risks, concerning either the probability of successful cooperation or the possibility of transaction costreduction. More recent definitions argue the need to conceptualize trust not only as calculative orientation towards risk, but also as a social orientation toward other people and societies as a whole. As recent research has demonstrated, one does not only 'think', but also 'feels' trust. Throughout research, various behaviors have appeared indicative of trust, such as cooperative behaviors including open communication, acceptance of influence, forbearance from opportunism, and lack of monitoring.

Although different, trust as a psychological state and trust as a choice of behaviors are in principle compatible approaches (Costa, 2004).

According to Nooteboom (2001), it is crucial to identify the differences between different behavior aspects, which are competencies and intentions. Some individuals assess the trust through competence plane, others - through intentions. In other words, individuals have different behavioral aspects in mind when assessing the trust. Some trust the competency, some - intentions, and there are those, whose realizations of the trust can be influenced by both behavioral aspects. As the literature review findings revealed, trust dimension definition is quite a complicated matter; therefore, it is beneficial to involve psychological, behavior, competency and intention trust in the research.

Trust dimension can be seen as a dynamic, ever-changing, depending on the interaction of various factors, a specific situation or a certain context, examined by the authors. All of these factors can affect the formation of trust in business relationships, since after all the trust is temporary.

The reasons of the trust formation. Trust is central to a successful relationship, because it encourages working at preserving relationship investments by cooperating with exchange partners, resisting attractive short-term alternatives in favor of the expected long-term benefits and viewing potentially high-risk options as being prudent because of the belief that their partners will not act opportunistically (Mukherjee and Nath, 2003).

Different reasons why organizations are trying to form a trust can be excluded, but the most important reason is that trust is essential for a strong and successful collaboration between business partners, since: 
- the trust reduces the need for control and has a direct impact on the effectiveness of the control methods;

- the trust encourages organizations to commit;

- the trust helps to reduce the perceived risk and the perceived relations between operational risks and helps to bear;

- the trust helps to resolve conflicts and promote tolerance among organizations;

- the trust promotes the sharing of information and knowledge among organizations;

- the trust encourages inter-organizational innovation adoption.

One of the reasons to form the trust is striving to minimize the control or make it more efficient. Scientists have different point of view regarding the interaction between trust and control. According to Vourenmaa (2006), the trust is a control mechanism, where trust and control act as substitutes; in addition, confidence and control complement each other. However, Das and Teng (2001) argue that trust can partialy replace the extent of the control, since a higher degree of trust reduces the need for control and confidence drop increases the need for control. Thus, according to Mohr (2003), there is a negative correlation between trust and control: trust reduces the need for control and strong control leads to a decrease in confidence.

According to Knights, Noble, Vurdubakis and Willmott (2001), trust and control can act as substitutes for one another, because both trust and control are related by the desire to reduce uncertainty and increase the predictability of the business partner's behavior (Vlaar, 2006).

Organization strives for a higher level of mutual trust in order to reduce the need for control, for several reasons. First, greater control requires more effort, cost and time. In addition, according to Beck and Kieser (2003), a very high level of control and coordination can be harmful to the organization's activities (Vlaar, Bosch and Volberda, 2006). According to Ring and Van de Ven (1994), excessive control leads to conflicts and disagreements between business partners (Vlaar, Bosch and Volberda, 2006). Consequently, over-control is more harmful than helpful; therefore, control reduction, due to the trust increase, might solve the issues associated with the excessive control. According to Das and Teng (2001), trust has the impact on the effectiveness of the control methods. Also, control and monitoring implementation of the organizations require a certain level of confidence. Trust increases the effectiveness of the control, since it reduces the level of resistance and brings harmony between the controller and the one, who is controlled. In addition, trust reduces the possibility of retaliation because partners, who share the trust, are more likely to develop mutual understanding and tolerance. Based on Vuorenmaa (2006), trust is seen as particularly necessary for the implementation of effective control, even under circumstances where there is a possibility to apply strict controls, as stringent controls do not provide positive results if there is no trust between the partners. In addition, according to Das and Teng (2001), trust can be intermediary between the control mechanism and achieved control level. In other words, in order to achieve an effective level of control, it requires a certain level of trust otherwise the control cannot be justified. As the findings revealed, an effective control can be achieved only if there is a minimal trust between partners. 
According to Krishnan and Martin (2006), trust is particularly important when organizations strive for an open and strong commitment towards each other. Goo and Nam (2007) admit that trust has a positive impact on the commitment, which is necessary for organizations' inner-relationship. Moreover, according to Hakansson and Snehota (1995) and Morgan and Hunt (1994), trust is a precursor of commitment because it is based on experience and knowledge of the business partners' behavior; therefore, the trust leads towards the thoughts about the future, and eventually, partners engage in the commitment (Cater, 2006).

According to Das and Teng (2001), trust lowers the level of risk and contributes towards its assumption. Trust can impact the realization of the subjective risk, but has no impact on the objective, a factual one. The critical difference between risk and perceived risk needs to be noted. Risk (or objective risk) is based on the consequences or outcomes of alternatives and their probabilities. Risk can be objective because it is something inherent in given situations. In many cases, such as lottery and card games, risk can be objectively calculated, based on known possible outcomes and their probabilities. On the other hand, perceived risk (or subjective risk) is decision makers' estimate of objective risk (Dowling, 1986; Fischhoff, 1985). Decision makers, thus, may have different estimates about the level of risk in a given situation.

While trust reduces perceived risk, it may not reduce actual risk inherent in the relationship. Because trust is a state of mind rather than an action, it does not do anything about objective risk in a relationship. Nevertheless, as a positive expectation about others, trust does lead to a perception of lowered risk in a relationship. In this sense, it is maintained that perceived risk is reduced (or lowered) by the presence of trust. Besides, if trust leads to behavioral reliance on the trustee, then the trustor voluntarily becomes vulnerable to the actions of the trustee (Mayer et al., 1995). This may actually increase the risk to the trustor. Similarly, control does not always reduce objective risk, as it may be only an 'illusion of control'. Besides, firms may opt for control that is excessive (Garnsey and Wilkinson, 1994), precluding increased productivity that may accrue if a degree of autonomy is granted in alliances. Accordingly, risk, as used in this article, refers to subjective or perceived risk rather than objective risk (Das and Teng, 2001).

When there is neither trust, nor prior experience, organizations can take other steps to reduce the perceived risk, but in some situations, a business relationship between the participant's risk reductions could mean another increase in risk. Knowledge of the business partner is accumulated over a period of time, both in direct contact and indirectly getting information from independent third parties. Where there is doubt touching freight exchange, the partners try to use tactics to minimize the perceived risk by looking into various suppliers and engaging into activity with a well-known supplier, with whom they have worked in the past. Usually, partners are strongly attracted to those participants, who are less risky. Organizations are more likely to sell or buy from those suplliers, with whom they have had contact in the past. Changing the partner could lead into to high conversion costs, since the process of building the trust is usually associated with financial recources, as well.

According to Krishnan and Martin (2006), partners, who share the trust, are more tolerant to each other's unusual behavior, which is explained by the need to maintain the 
stability of the relationship. Overall, the trust contributes towards conflict mitigation and tolerance increment within the partnership. Lane (2000) agrees that trust has the impact on the inter-organizational tolerance increase and also facilitates the solution of the conflict (Thuy and Quang, 2005).

Ellonen, Blomqvist and Puumalainen (2008) emphasize the fact that trust has the impact on partners' willingness to share the knowledge and information. It could be concluded from these various research results that there is a substantial support for the assumption that high levels of trust have a positive effect on the effectiveness and quality of organizational knowledge sharing and innovation. Trust helps to curb the motivation of the partners to behave opportunistically and allows making the organizational interface more leakage-proof (Kale et al., 2000; Janowicz and Noorderhaven, 2002). If one party trusts the other, it perceives less risk in divulging relevant, comprehensive, accurate and timely or proprietary information to the other (Chiles and MacMackin, 1996). In contractual relationships lacking in trust, on the other hand, information exchanged may be inaccurate, incomprehensive and untimely (Janowicz and Noorderhaven, 2002). Trust will be critical if two situational factors are present: risk and incomplete information (Hawes, 1989). Since most transactions present some degree of risk and uncertainty, trust acts as an information resource rather than reduces the perceived threat of information asymmetry and performance ambiguity. Trust enables exchange partners to adopt schemas, which leave them free to act without trying to process more information than they are capable of handling (Tomkins, 2001), or where they are unable to acquire sufficient information about future events (Batt, 2003).

Trust enables innovation adoption in the organization. According to Ellonen, Blomqvist and Puumalainen (2008), a high level of trust has a positive impact on creating favorable conditions for innovation, since it lowers the perception of partners' possible opportunistic behavior and also promotes an open communication, commitment and willingness to share knowledge and information.

It can be argued that trust dimension defines business partners' need to minimize the control, increase the degree of mutual commitment, increase the dissemination of knowledge and information, promotes innovation, and therefore, identification and expression of these reasons could be one of the objectives in the trust assessment case.

\section{Empirical and methodological aspects of trust assessment}

In order to highlight the methodological aspects of trust evaluation, it is important to understand what are the main characteristics or conditions, which define the trust, what are trust evaluation criteria. There is plethora of trust components defined in the scientific literature; therefore, it is quite complicated to identify the most important ones.

Trust evaluation criteria/componnets. According to Martins (2002), trust criteria could be the following: integrity, competence, vulnerability, reliability, expectations. Mayer et al. (1995) distinguish between these components: ability trust, benevolence trust, integrity trust (Wiethoff and Lewicki, 2005). Moorman (1993) reveals trust concept using these components: perceived expertise, sincerity, integrity, tactfulness, timeliness, confidential- 
ity. Therefore, Mayer argues that trust components are best identified using these criteria: ability, benevolence, integrity (Batt, 2003). Unambiguously, the authors use these trust conditions, which could assess the trust among business partners. Unfortunately, until today, there has been no solid systematic measuring system, although after expiration of various opinions and views regarding trust definition, the following criteria/components are being distinguished as having the most impact on the trust within business partners:

- Competence/ability;

- Foresight/perceptiveness;

- Honesty/promise keeping;

- Reputation/image;

- Goodwill/altruism;

- Trust/openness;

- Tolerance, respect, tactfulness.

Trust evaluation criteria are closely associated, intertwined and, in some cases, different literature sources duplicate one another. Reliability in both aspects, business partner representatives (individuals) and the organization as a business partner, is assessed by the full set of trust criteria. Which components are selected for the research mostly depends on the specifics of a planned research.

Empirical research results of the trust criteria. Trust criteria at the individual level are related to individual's need to develop certain characteristics. In this regard, decision was made to survey students, studying in business, economics and finance programs. The research was performed by surveying Mykolas Romeris University bachelors and masters students, studying in Business and Economics programs in 2012. The respondents were being asked "What personal traits do you think are the most important for the entrepreneur?" Criteria used in the survey were selected those, which might be important in the trust dimension assessment.

In 2011-2012, N students studied in these programs. According to the Panniot formula, a sample of 393 students was needed to get representative results. In this research, answers of 420 students were used to get the results. It is important to emphasize the fact that part of the students were employed or had their own business. Likert scale was applied in the survey with values 1 (not important) to 5 (extremely important). Survey results were processed using SPSS statistical program with a permissible 5 percent error. In order to identify the links between the criteria, correlation analysis was applied. Pearson correlation coefficient allowed the assessment of the linear relationship strength.

Table 1. The necessity of individual traits, associated with a trust in business correlation coefficient

\begin{tabular}{|c|c|c|c|c|c|c|c|}
\hline Pearson Correlation & $\mathbf{1 .}$ & $\mathbf{2 .}$ & $\mathbf{3 .}$ & $\mathbf{4 .}$ & $\mathbf{5 .}$ & $\mathbf{6 .}$ & $\mathbf{7 .}$ \\
\hline 1. Foresight/perceptiveness & 1 & & & & & & \\
\hline$N$ & 422 & & & & & & \\
\hline 2. Honesty/promise keeping &, $184^{* *}$ & 1 & & & & & \\
\hline$N$ & 422 & 423 & & & & & \\
\hline
\end{tabular}




\begin{tabular}{|c|c|c|c|c|c|c|c|}
\hline 3. Competence/ability &, $343^{* *}$ &, $333^{* *}$ & 1 & & & & \\
\hline$N$ & 422 & 423 & 423 & & & & \\
\hline 4. Reputation/image & $237^{\star *}$ &, $148^{* *}$ & $236^{\star *}$ & 1 & & & \\
\hline$N$ & 422 & 423 & 423 & 423 & & & \\
\hline 5. Goodwill/altruism & 073 &, $474^{\star *}$ &, $214^{* *}$ &, $115^{*}$ & 1 & & \\
\hline$N$ & 422 & 423 & 423 & 423 & 423 & & \\
\hline 6. Tolerance, respect, tactfulness &, $178^{\star *}$ &, $466^{* *}$ &, $237^{\star *}$ & $200^{* *}$ & $491^{\star *}$ & 1 & \\
\hline$N$ & 422 & 423 & 423 & 423 & 423 & 423 & \\
\hline 7. Trust/openness &, 064 &, $370^{* *}$ &, $186^{* *}$ &, $133^{* *}$ &, $462^{\star *}$ &, $430^{* *}$ & 1 \\
\hline$N$ & 421 & 422 & 422 & 422 & 422 & 422 & 422 \\
\hline
\end{tabular}

* Correlation is significant at the 0.05 level (2-tailed).

$* *$ Correlation is significant at the 0.01 level (2-tailed).

According to the research results, obtained values almost in all cases (18 out of 12) were statistically significant $(p=0,000<0,01)$. The strongest correlation was identified between these individual traits associated with a trust in business:

- Goodwill/altruism and honesty/promise keeping with correlation coefficient of $0,474^{\star *}$; tolerance, respect, tactfulness with correlation coefficient $0,491^{\star *}$; trust/openness confirmed correlation of $0,462^{* *}$.

- Honesty/promise keeping and tolerance, respect, tactfulness revealed correlation coefficient of $0,466^{* *}$; trust/openness showed correlation coefficient of $0,370^{* *}$.

- Trust/openness and tolerance, respect, tactfulness showed a correlation coefficient of $0,430^{* *}$.

It can be argued that along with the increase of personal traits, which would be associated with the trust in the business environment, there is a defiant need for other traits, as well, and vice versa. It can be stated that at the confidence level of 95 percent, trust criteria and their need, in business in a sense of legitimacy, are statistically significantly associated. In trust dimension within business relationship identification, coverage is a complex process, which leads towards the need for a further in depth research study. The emphasis on the trust research direction develops methodological base, which allows performing investigations regarding trust formation within partnerships. The emphasis on the trust components has created a methodological framework, which might be usefull in performing the research study analyzing inter-organizational trust formation possibilities.

\section{Conclusion}

After analyzing organizations' trust among business partners' formation and assessment theoretical assumptions and highlighting trust assessment methodological aspects, the following conclusions were formed.

The concept of trust is very diverse and mainly depends on the research problem, which is subjective to the author's point of view. Some authors think of trust as a psychological state, while others think of trust as a behavioral aspect. In addition, there is the third 
opinion, which argues that these two approaches can go together. Also, trust dimensions in business relations are closely related to risk, vulnerability, expectations and other factors.

Trust dimensions can exist at different levels, such as individual, organizational and inter-organizational. In addition, trust among organizations can be explored within individual, group of individuals or organizational level. Variety of reasons affect trust in business relations process formation and development, which cause certain advantages, such as willingness of business partners to minimize the control and increase the efficiency, increase of mutual commitment degree, facilitation of the conflict resolution, increase in tolerance, and the enhancement in knowledge and information dissemination as well as innovation implementation.

The assesment of trust dimension in business relations is closely related to the criteria identification, including competence/ability, foresight/perceptiveness, honesty/ promise keeping, reputation/image, goodwill/altruism, trust/openness, tolerance, respect, tactfulness. These trust criteria are closely related, yet their components can vary depending on the research study being performed. The empirical study revealed that certain individual traits are necessary to build trust in business. Statistical data results showed that the respondents paid less attention towards goodwill and altruism, with the enhanced emphasis on the competencies/ability and reputation/image. Estimates of the correlation analysis showed that there is a week positive statistically significant relation among all criteria used to identify the trust.

Trust enhances the efficiency of business and is an inherent condition for any type of relations as well as for the appearance of business relations among partners. Although, despite the necessity of trust existence, the assesment of trust for business partners is a complicated and complex task to be solved, which requires further research studies within organizational and inter-organizational level.

\section{References}

1. Ambrose, E.; Fynes, B. Trust in Supply Chain Relationships - Issues of Measurement. 3rd EIASM Workshop on Trust within and between Organizations. Brussels, 27 October 2005 [interactive]. <http://www.ctvr.ie/docs/O\&M_Pubs/EAISM\%20 Trust\%20Workshop. pdf >.

2. Batt, P. J. Building Trust between Growers and Market Agents. Supply Chain Management: An International Journal. 2003, 1(8): 65-78.

3. Cater, B. A Three-component Model of Commitment in Professional Service Relationships on Business-to-business Markets. 14th International Colloquium in Relationship Marketing. Leipzig/Germany, September 13th-16th 2006, p. 18 [interactive]. $<$ http://www.icrm2006.uni-leipzig.de/fileadmin/ICRM/14-1-2_-_Cater_Paper.pdf>.

4. Costa, A.C. Trust in Organizations. In Spielberg (Ed.) and J.M. Prieto (section Ed.). Encyclopedia of Applied Psychology. Volume 3. Elsevier: Academic Press, 2004, p. 611620.

5. Das, T. K.; Teng, B. S. Trust, Control, and Risk in Strategic Alliances: An Integrated Framework. Organization Studies. March 2001 (22): 251-283. 
6. Ellonen, R.; Blomqvist, K.; Puumalainen, K. The Role of Trust in Organisational Innovativeness. European Journal of Innovation Management. 2008 (11, 2).

7. Goo, J.; Nam, K. Contract as a Source of Trust - Commitment in Successful IT Outsourcing Relationship: An Empirical Study. In HICSS Proceedings of the 40th Hawaii International Conference on System Sciences. 2007, p. 239.

8. Janowicz, M.; Noorderhaven, N. The Role of Trust in Interorganizational Learning in Joint Ventures. Paper provided by Tilburg University, Center for Economic Research in its series Discussion Paper with number 2002-119, p. 37. <http://arno.uvt.nl/ show.cgi? fid $=4417>$.

9. Krishnan, R.; Martin, X. When Does Trust Matter to Alliance Performance? Academy of Management Journal. 2006, 49(5): 894-917.

10. Lewicki, R. J. Trust and Distrust. 2006, p. 12 [interactive]. <http://www.abanet.org/ abastore/products/books/abstracts/4740062chap22.pdf $>$.

11. Martins, N. A Model for Managing Trust. International Journal of Manpower. 2002, 8(23): 754-769.

12. Mohr, A. T. The Relationship between Trust and Control in International Joint Ventures (IJVs) - An Empirical Analysis of Sino-German Equity Joint Ventures. 2003 [interactive]. <http://www.researchgate.net/publication/228368716_The_relationship_between_Trust_and_Control_in_International_Joint_Ventures_(IJVs) An_empirical_analysis_of_Sino-German_Equity_Joint_Ventures $>$.

13. Mukherjee, A.; Nath, P. A Model of Trust in Online Relationship Banking. International Journal of Bank Marketing. 2003, 1(21): 5-15.

14. Nooteboom, B. Learning and Governance in Inter-firm Relations. 2001, p. 27 [interactive]. < http://papers.ssrn.com/sol3/papers.cfm?abstract_id=370940>.

15. Payan, J. M. Multiple Levels of Trust and Dependence on Supplier-Distributor Coordination: An Empirical Test. The Marketing Management Journal. 2006, 16(1): 125-137.

16. Skinner, D.; Spira, L. F. Trust and Control - A Symbiotic Relationship? Corporate Governance. 2003, 4(3): 28-35.

17. Tejpal, G.; Garg, R.K.; Sachdeva, A. Trust among Supply Chain Partners: A Review. Journal Measuring Business Excellence. 2013, 1(17): 51-71. Q Emerald Group Publishing Limited.

18. Thuy, L. X.; Quang, T. Relational Capital and Performance of International Joint Ventures in Vietnam. Asia Pacific Business Review. 2005, 11(3): 389-410.

19. Vlaar, P. W. L. Making Sense of Formalization in Interorganizational Relationships: Beyond Coordination and Control. Doctoral Thesis. Rotterdam: Erasmus University, 2006 [interactive]. <http://publishing.eur.nl/files/vdbosch/res/publications/7326/>.

20. Vlaar, P. W. L.; Van den Bosch, F. A. J.; Volberda, H. W. On the Evolution of Trust, Distrust, and Formal Coordination and Control in Interorganizational Relationships: Towards an Integrative Framework. 2006, p. 34, [interactive]. <http://papers.ssrn. com/sol3/papers.cfm?abstract_id=920230>.

21. Vuorenmaa, E. Trust, Control and International Corporate Integration. 2006, p. 251 [interactive]. <https://www.utu.fi/fi/yksikot/tse/yksikot/laskentatoimi-ja-rahoitus/ opiskelu/Documents/Vuorenmaa_v\%C3\%A4ikk\%C3\%A4ri.pdf>. 
22. Wehmeyer, K.; Riemer, K. Trust-Building Potential of Coordination Roles in Virtual Organizations. The Electronic Journal for Virtual Organizations and Networks. 2007, 8: 102-123 [interactive]. <http://www.ejov.org/projects/264/Issues/eJOV\%20Vol8/ eJOV8_5_Wehmeyer_Riemer_Trust-building\%20potential.pdf $>$.

23. Wiethoff, C.; Lewicki, R. J. Trust and Distrust in Work Relationships: A Grounded Approach. 2005, p. 20 [interactive]. <http://papers.ssrn.com/sol3/papers.cfm? abstract_id=736273>.

24. Woolthuis, R. K.; Hillebrand, B.; Nooteboom, B. Trust and Formal Control in Interorganizational Relationships. 2002, p. 24 [interactive]. <http://papers.ssrn.com/sol3/ papers.cfm?abstract_id=370957>.

25. Zanini, M. T.; Musante, M. Trust in the Knowledge Economy. Journal of Business \& Industrial Marketing. 2013, 6(28): 487-493.

\section{PASITIKĖJIMO DIMENSIJA VERSLO SANTYKIUOSE}

Santrauka. Pastaraisiais metais pasitikejjimo dimensija verslo santykių kontekste sulaukè daugiau užsienio mokslininkų dèmesio. Susidomejjimą šia tyrimo sritimi, viena vertus, lèmé verslo aplinkos pokyčiai. Kita priežastis - teigiamas pasitikejjimo poveikis kuriant ir pletojant našius ir naudingus tarpusavio santykius skirtingose verslo srityse. Pasitikejjimas padidina verslo funkcionavimo efektyvumą ir yra būtina sąlyga bet kokiems santykiams, taip pat ir santykiams tarp verslo partnerių, atsirasti ir plètotis. Pasitikejimas organizacija reiškia pasitikẻjimą žmonèmis, dirbančiais toje organizacijoje, todèl dažnai jis yra nagrinejamas psichologiniu ir elgesio aspektais. Pasitikejjimo verslo partneriais vertinimas yra sudètingas ir kompleksiškai sprendžiamas uždavinys. Norint j̇vertinti pasitikejjimo formavimosi priežastis, svarbu identifikuoti pasitikèjimo vertinimo kriterijus tiek individų, tiek ir organizacijų lygmeniu. Išanalizuota pasitikejjimo dimensijos verslo santykiuose apreptis leidžia atskleisti pasitikejjimo, kaip tyrimo objekto, sandarą ir turinị, lygius ir formas, pasitikèjimo formavimosi priežastis ir vertinimo kriterijus bei reikalauja tolesnių organizacinio bei tarporganizacinio lygmens tyrimų.

Eglè KAZLAUSKIENĖ, Doctor in Economics, Professor in Economics and Management Institute, Head of research programme "National Sustainable Growth in the Context of Globalisation". Research interests: business systems, organizational networks, problems of services business and development.

Eglè KAZLAUSKIENĖ - Mykolo Romerio universiteto Ekonomikos ir vadybos instituto profesorè, ekonomikos mokslų daktarè. Mokslo programos „Šalies darni plètra globalizacijos sąlygomis" vadovè. Mokslo tyrimų sritys: verslo sistemos, organizacijų tinklai, paslaugų verslo ir plètros problemos.

Ilona BARTUŠEVIČIENĖ, Mykolas Romeris University, Doctoral student in Economics. Research interests: intangible assets, economic efficiency.

Ilona BARTUŠEVIČIENE் - Mykolo Romerio universiteto ekonomikos krypties doktorantė. Pagrindinès tyrimų sritys: nematerialūs ištekliai, ekonominis efektyvumas. 